\title{
Kitty Clive, or The Fair Songster
}

Cunningham, John

\section{Eighteenth Century Studies}

DOI:

https://doi.org/10.1353/ecs.2021.0053

Published: 05/05/2021

Peer reviewed version

Cyswllt i'r cyhoeddiad / Link to publication

Dyfyniad o'r fersiwn a gyhoeddwyd / Citation for published version (APA):

Cunningham, J. (2021). Kitty Clive, or The Fair Songster. Eighteenth Century Studies, 54(3), 734-736. https://doi.org/10.1353/ecs.2021.0053

\footnotetext{
Hawliau Cyffredinol / General rights

Copyright and moral rights for the publications made accessible in the public portal are retained by the authors and/or other copyright owners and it is a condition of accessing publications that users recognise and abide by the legal requirements associated with these rights.

- Users may download and print one copy of any publication from the public portal for the purpose of private study or research.

- You may not further distribute the material or use it for any profit-making activity or commercial gain

- You may freely distribute the URL identifying the publication in the public portal ?
}

Take down policy

If you believe that this document breaches copyright please contact us providing details, and we will remove access to the work immediately and investigate your claim. 


\section{JOHN CUNNINGHAM, Bangor University, Wales}

Berta Joncus, Kitty Clive, or The Fair Songster (Woodbridge: The Boydell Press, 2019). Pp. xiv $+527 . \$ 99.00$ Hardback.

Catherine 'Kitty' Clive (née Rafor) (1711-1785) was one of the first female stars of the London stage. Born in London to a disgraced Irish Catholic father, William Raftor, in 1733 she assumed her married name from the barrister George Clive. Between her debut in 1728 and retirement in 1769 , on the London stage Clive acted and sang in a range of productions (plays, masques, ballad operas, oratorios, operas etc.) including Dalila in Handel's Samson (1743). Her career coincided with the rise of the English press media and its increasing construction of celebrity. Her star power brought with it financial rewards, which ultimately contributed to the public turning on her in the 1740s, leaving Clive to throw her lot in with David Garrick and in the process abandoning and disparaging the serious song through which she had built her career. In this remarkable book Berta Joncus tells the enthralling story of this equally remarkable heroine.

The name Kitty Clive will, of course, be familiar to anyone with an interest in the eighteenth-century London stage; her modern reputation is largely founded on her acting skills. Over 13 substantial chapters, Joncus paints a detailed picture of Clive not simply as an actress but as one highly conscious of her self-image and an active participant in its construction. In addition to her meticulous analyses of the theatrical contexts and the works and roles which Clive inhabited, Joncus explores too the visual representations of Clive in portrait and porcelain. While Clive is generally considered foremost as an actress today, Joncus demonstrates that in fact Clive's singing and musicianship and musical training were essential elements in her success. Moreover, the "modern ignorance of Clive as initially a celebrated songster, and then a first comedienne-soprano, stems largely from eighteenth-century writings, including Clive's." (4) The book examines Clive's singing career until around 1750. Joncus explains how in this first half of her singing (rather than acting) career Clive used song as a means of bonding with her audience, through improvisation, direct address, and parodying imitations; after 1750 serious song ceased to be an important aspect of Clive's repertory. Naturally this leaves a substantial portion of Clive's career unexplored but there is more than enough here to present a major reassessment of this largely neglected star of the eighteenth-century stage.

Joncus begins with an evocative exploration of Clive's modern reputation, its construction in the eighteenth century, and the emerging culture of stardom and public identity. In the chapters that follow Joncus shows how Clive's representation and reputation changed. In the 1720s she trained with the ill-fated Henry Carey, who in Clive saw an ideal student with the potential to realize his theatrical ambitions. Clive's emergence coincided with The Beggar's Opera, with Lavinia Fenton's star in rapid ascent as Polly Pecham. At the rival Drury Lane Colley Cibber sought to stage a ballad opera based on virtue and innocence, with Clive as the leading lady opposite Cibber himself: Carey's Love in a Riddle. The poor quality of the work and Cibber's own lack of singing ability (and self-awareness) were rescued by Clive's own performance. And so Clive's early image of propriety and seriousness was born, as was her reputation as a singer. The next few years brought continued success in both serious and comic roles, culminating in the 1732-33 season. Sexuality and gender are recurring themes in the book. Joncus debunks the idea that Clive's "marriage" in 1733 was anything but a sham, another role to be played, arguing that the marriage never took place. Instead it was a marriage of 
convenience to hide both George and Kitty's attractions not to each other but to members of their same sexes.

While Clive's status was growing she also became embroiled in several rows and scandals that eventually broke her reputation in the 1740s. For example, in the so-called 'Polly Row' (1736-37) she successfully challenged through the media her rights to her parts, as Theophilus Cibber sought to instate his wife, Susannah, to the role of Polly: a role which Clive by then considered her own. With public opinion on her side, Clive prevailed: a significant victory for a female actress. In the late 1730s Clive established herself as the Shakespearean soprano in the revivals mounted (most likely) by the Shakespeare Ladies' Club. Thomas Arne would of course go on to write several songs in the Drury Lane revivals of the early 1740s: some of which endured well into the next century. The volatility of theater politics, however, made negotiation of the public space and image hazardous even for a star such as Clive, who was caught in the crosshairs of the Actor's Rebellion of 1743-44. In defending himself against the petition of the Drury Lane actors, the manager Charles Fleetwood published Clive's salary second only to David Garrick's. Her claims to modesty were becoming ever open to question in the media and among her audience. It was a reported clash in the green room with her rival Peg Woffington, however, that ultimately damaged Clive's public reputation. As accounted in the broadside ballad, The Green Room Scuffle (1746), the rivals had a heated exchange. Whatever the truth, as Joncus notes, it became a watershed moment in Clive's career. From the carefully constructed representative of British taste and propriety of her early years, Clive was now viewed as an indulgent drama queen. The change in public perception forced Clive into a reinvention as a deprecating self-parody. In 1750 she wrote and staged her first play, The

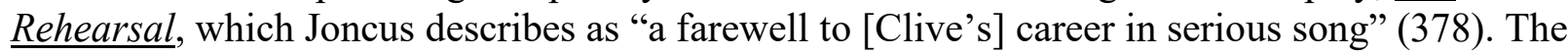
second half of her career had now begun, in which she was forced to satirical portrayals in a bid to reconnect with London audiences, ridiculing Italian operas and their singers.

The short summary presented here does no justice to the complexity of the story which Joncus details. The prose is eminently readable and she offers highly perceptive readings of both texts and contexts. Joncus sets out to emphasize the importance of Clive's voice in her career and her self-representation. There are numerous discussions of the songs, though they tend towards interpretation of meaning and how audiences might understand them as songs. There are three appendices. The first tabulating Clive's roles throughout her career (1728-69), 222 in total; the second tabulating lines in her repertory according to character types; the third a transcription of "The Case of Mrs. Clive" published by Clive in response to her critics in 1744. However, we get no comprehensive account of Clive the singer: for example, her vocal range as can be deduced from the surviving songs, nor indeed even an easily extracted account of the songs that do survive and those for which music does not. Indeed, while the bibliography is impressively comprehensive there is no discography (or accompanying online tracks as one sometimes finds), which is rather surprising given the tenor of the book. One cannot do everything, but such things might have brought us a little closer to understanding Clive as a singer and not just as a songster.

The price tag is high (as most academic books seem to be these days), but it is nevertheless worth it. Boydell consistently issue handsomely produced books and this is no exception. The copious illustrations and music examples support the arguments in the text amply (though some of the facsimile reproductions are a little small). Indeed, given the clearly high standard of the book it is disappointing that more care was not taken with the music examples to render them consistent: some are rather over-sized, and unlike the detailed "Conventions of Transcription" (xiv) that govern the text elements there seems to have been no overarching 
editorial method for the music examples, arguably more necessary given that they were done by at least three people. This quibble while aesthetically irksome does not, however, detract from the impressive scholarship that this book represents. Simply put, it is essential reading for anyone interested in the eighteenth-century London stage and the wider culture it not only represented but from which it was born. A star is re-born. 